\title{
Jurist-Diction
}

Volume 2 No. 6, November 2019

Histori artikel: Submit 19 September 2019; Diterima 16 Oktober 2019; Diterbitkan online 1 November 2019.

\section{Perlindungan Hukum Terhadap Atlet Pelatihan Daerah Dengan Organisasi Komite Olahraga Nasional Indonesia Terkait Kontrak Kerja}

\author{
Dio Novandra Wibawa \\ monalady01@gmail.com \\ Universitas Airlangga
}

\begin{abstract}
Sport is one of the activities that cannot be separated from daily life, but who would have thought that it turns out that sports can also make money and can also be categorized in labor law. In this case, an achievement athlete who is part of a regional training center will act as a worker who is given work, orders and wages by the organization of the Indonesian National Sports Committee, which here acts as an employer. Between athletes and organizations that respond to athletes can cause a work relationship to arise when a work agreement or decree has been made and agreed upon by both parties. However, as time goes by, actual disputes have not been regulated in the agreement clauses made in the beginning, namely concerning rights disputes and labor relations disputes. Because of the dispute arising, then look for ways in the legal literature in Indonesia to resolve the dispute.
\end{abstract}

Keywords: Sports; Athletes; Organization of the Indonesian National Sports Committee; Labor; Disputes.

\begin{abstract}
Abstrak
Olahraga adalah salah satu kegiatan yang tidak dapat dipisahkan dari kehidupan sehari-hari, namun siapa sangka bahwa ternyata olahraga juga dapat menghasilkan uang dan dapat pula dikategorikan dalam hukum perburuhan. Olahraga suatu bentuk aktivitas fisik yang terencana dan terstuktur yang melibatkan gerakan tubuh berulang-ulang dan ditujukan untuk mwningkatkan kebuguran jasmani. Dalam kasus ini, seorang atlet prestasi yang tergabung dalam pusat latihan daerah akan berperan sebagai buruh yang diberikan pekerjaan, perintah, dan upah oleh organisasi Komite Olahraga Nasional Indonesia, yang disini berperan sebagai majikan. Antara atlet dan organisasi yang menauangi atlet tersebu menyebabkant timbul sebuah hubungan kerja adalah ketika perjanjian kerja atau surat keputusan telah dibuat dan disepakati oleh kedua belah pihak. Namun, seiring berjalannya waktu munculah perselisihan yang sebenarnya belum diatur dalam klausul perjanjian yang dibuat diawal yaitu mengenai perselisihan hak, dan perselisihan hubungan kerja. Oleh karena timbul perselisihan tersebut, maka dicarilah cara-cara di dalam literatur-literatur hukum di Indonesia untuk meyelesaikan perselisihan tersebut.
\end{abstract}

Kata Kunci: Olahraga; Atlet; Organisasi Komite Olahraga Nasional Indonesia; Perburuhan;

\section{Pendahuluan}

Dalam setiap kehidupan manusia, tujuan utama hidup bukanlah hanya mencari finansial semata, melainkan juga menjaga kebugaran tubuh agar tetap sehat dan awet muda. Hal tersebut yang akhir-akhir ini memang menjadi sebuah sorotan penting dan oleh sebab itu, menjaga tubuh adalah sebuah kewajiban yang mutlak. Namun, untuk membuat tubuh agar tetap bugar, sehat dan awet muda tidaklah 
mudah, dibutuhkan usaha yang keras serta terdapat berbagai macam cara yang kadang membuat kita menjadi semakin malas untuk melakukannya. Tetapi, terdapat salah satu cara yang paling praktis, mudah, dan murah dalam menjaga kebugaran tubuh adalah dengan cara rutin berolahraga. Olahraga adalah gerakan badan untuk menguatkan dan menyehatkan tubuh. ${ }^{1}$ Namun, menurut beberapa para ahli pengertian olahraga adalah sebagai berikut: ${ }^{2}$

"Hans Tandra mengatakan bahwa olahraga merupakan sebuah gerakan dari tubuh yang berirama atau mempunyai irama dan teratur guna memperbaiki serta meningkatkan kebugaran tubuh. Suryanto Rukmono mempunyai persepsi bahwa olahraga ialah suatu aktifitas atau kegiatan bagi tubuh yang diperuntukkan agar badan terasa sehat dan juga kuat secara rohani maupun jasmani”.

Lain hal pengertian olahraga menurut Undang-Undang Nomor 03 Tahun 2005 tentang Sistem Keolahragaan Nasional, olahraga adalah segala kegiatan yang sistematis untuk mendorong, membina, serta mengembangkan potensi jasmani, rohani, dan sosial. Lebih rinci lagi, Undang-Undang Nomor 03 Tahun 2005 tentang Sistem Keolahragaan Nasional membagi olahraga menjadi 6 (enam) jenis yaitu: ${ }^{3}$

1. Olahraga Pendidikan adalah pendidikan jasmani dan olahraga yang dilaksanakan sebagai bagian proses pendidikan yang teratur dan berkelanjutan untuk memperoleh pengetahuan, kepribadian, keterampilan, kesehatan, dan kebugaran jasmani.

2. Olahraga Rekreasi adalah olahraga yang dilakukan oleh masyarakat dengan kegemaran dan kemampuan yang tumbuh dan berkembang sesuai dengan kondisi dan nilai budaya masyarakat setempat untuk kesehatan, kebugaran, dan kegembiraan.

3. Olahraga Prestasi adalah olahraga yang membina dan mengembangkan olahragawan secara terencana, berjenjang, dan berkelanjutan melalui kompetisi untuk mencapai prestasi dengan dukungan ilmu pengetahuan dan teknologi keolahragaan.

4. Olahraga Amatir adalah olahraga yang dilakukan atas dasar kecintaan atau kegemaran berolahraga.

\footnotetext{
${ }^{1}$ KBBI, Olahraga, Kamus Besar Bahasa Indonesia (KBBI 2018) $<$ https://kbbi.web.id/olahraga/.> accessed 18 Februari 2019

${ }^{2}$ Vannisa, 'Pengertian olahraga secara umum \& menurut para ahli adalah, Perpustakaan Online Nasional', (Perpustakaan Nasional 2017) < https://perpustakaan.id/pengertian-olahraga-secara-umum-menurut-para-ahli-adalah/,> accessed 18 Februari 2019

${ }^{3}$ Pasal 1 Undang-Undang Nomor 03 Tahun 2005 tentang Sistem Keolahragaan Nasional Lembaran Negara Republik Indonesia Tahun 2005 Nomor 89.
} 
5. Olahraga Profesional adalah olahraga yang dilakukan untuk memperoleh pendapatan dalam bentuk uang atau bentuk lain yang didasarkan atas kemahiran berolahraga; dan

6. Olahraga Penyandang Cacat adalah olahraga yang khusus dilakukan sesuai dengan kondisi kelainan fisik dan/atau mental seseorang.

Berdasarkan penjelasaan diatas yang kemudian dalam pembahasan kali ini, penulis akan membahas tentang olahraga prestasi yang kemudian menuju pada sistematika olahraga prestasi di Indonesia.

Dalam olahraga prestasi, terdapat olahragawan yang biasa disebut dengan Atlet. Atlet adalah olahragawan, seseorang yang mengikuti perlombaan atau pertandingan dengan menggunakan kekuatan, ketangkasan, dan kecepatan dengan diikuti latihan secara berkala dan dinaungi oleh sebuah organisasi sebagai wadah yang memfasilitasi kegiatan latihan. ${ }^{4}$ Seorang atlet apabila telah meraih juara dalam sebuah pertandingan secara berturut-turut sebanyak tiga kali, maka atlet tersebut akan dikategorikan sebagai atlet pretasi. Pengertian prestasi menurut UndangUndang Nomor 03 Tahun 2005 tentang Sistem Keolahragaan Nasional adalah hasil upaya maksimal yang dicapai olahragawan atau kelompok olahragawan (tim) dalam kegiatan olahraga. Namun, atlet prestasi tidaklah semata-mata hanya manusia yang dikatakan sempurna secara fisik melainkan manusia yang tergolong dalam penyandang cacat juga dapat menjadi atlet prestasi. Selain itu, seorang atlet prestasi tidaklah dapat dipandang sebagai mandiri, karena dibalik kesuksesannya juga terdapat faktor pedukung lain yaitu organisasi yang mewadahi kegiatan pelatihan dan mengawasi kegiatan pelatihan tersebut. Di Indonesia, terdapat sebuah wadah yang menaungi atlet-atlet prestasi baik atlet yang tergolong normal maupun atlet yang tergolong dalam penyandang cacat untuk membentuk karakter, melakukan pembinaan dan pengembangan, menangani fasilitas terkait, serta mengawasi perkembangan atlet, wadah yang dimaksud tersebut adalah Komite Olahraga Nasional Indonesia atau yang biasa disebut dengan KONI yang berbentuk sebuah organisasi. Dalam menjalankan tugasnya, Komite Olahraga Nasional Indonesia

\footnotetext{
${ }^{4}$ KBBI, Atlet, Kamus Besar Bahasa Indonesia (KBBI 2018) < https://kbbi.web.id/.>accessed 18 Februari 2019.
} 
(KONI) berpegang teguh atas Undang-Undang Dasar 1945 yang menjadi acuan dasar negara sebagai dasar pembentukan organisasi dalam membina dan mengawasi atlet. Undang-Undang yang dimaksud dan dijadikan dasar oleh Komite Olahraga Nasional Indonesia (KONI) adalah Undang-Undang Nomor 03 Tahun 2005 tentang Sistem Keolahragaan Nasional dan Keputusan Presiden Republik Indonesia Nomor 72 Tahun 2001 tentang Komite Olahraga Nasional Indonesia.

Pada dasarnya, dalam program pembinaan dan pengembangan pelatihan atlet prestasi dibutuhkan pula peran pendukung yang lebih mengawasi langsung, mendampingi secara intensif, serta bertanggungjawabdan bertugas atas pembentukan atlet. Pendukung yang dimaksud dalam pembicaaran di atas adalah seorang Pelatih. Pelatih adalah orang yang melatih (olahraga dan sebagainya) serta yang mengenal langsung karakter pribadi atlet prestasi secara personal. Namun, pelatih dalam hal ini bukanlah asal pelatih yang dapat melakukan pengawasan, pendampingan, dan pembentukan kepada para atlet, melainkan pelatih yang memang telah terdaftar dan berada dibawah naungan Komite Olahraga Nasional Indonesia (KONI) yang kemudian pelatih tersebut ditugaskan dalam sebuah perkumpulan olahraga yang bersangkutan. Sejak tanggal pertama ditugaskan dalam sebuah perkumpulan olahraga yang bersangkutan, maka sejak saat itulah pelatih tersebut diberi amanah untuk melakukan pengawasan, pendampingan serta bertanggungjawab atas pembentukan atlet prestasi agar dapat mencapai target yang telah ditentukan pada awal para atlet ditunjuk bahwa mereka masuk dalam kategori atlet prestasi.

Di Indonesia, bentuk pengaturan tentang atlet yang tergolong dalam Olahragawan Prestasi Unggulan Daerah dinyatakan dalam Peraturan Menteri, yaitu Peraturan Menteri Pemuda dan Olahraga Republik Indonesia Nomor 21 tahun 2017 tentang Pembinaan dan Pengembangan Cabang Olahraga Prestasi Unggulan Daerah yang selanjutnya disingkat Permen Nomor 21 Tahun 2017. Berdasarkan Permen Nomor 21 Tahun 2017 terdapat pengaturan mengenai hak dan kewajiban yang tertuang dalam Bab III Pasal 5-10 tentang Tugas, Kewenangan, dan Tanggungjawab dibebankan kepada 5 instansi yaitu, pada Pemerintah, Pemerintah Daerah, Komite Olahraga Nasional Indonesia, Induk Organisasi Cabang Olahraga, dan Perkumpulan 
Olahraga Prestasi. Namun dalam peraturan menteri tersebut tidak secara gamblang mengatur terkait hak dan kewajiban seorang atlet yang masuk dalam kategori olahragawan prestasi unggulan daerah. Tetapi pengaturan terhadap hak dan kewajiban tersebut dikelola langsung oleh Pemerintah Daerah, Komite Olahraga Nasional Indonesia, Induk Organisasi Cabang Olahraga dan Perkumpulan Olahraga Prestasi. Perkumpulan olahraga tersebut yang wajib menyertakan hak dan kewajiban seorang atlet yang tergolong dalam kategori olahragawan prestasi unggulan daerah.

Apabila seorang atlet sudah dikategorikan dalam atlet prestasi maka, atlet tersebut akan masuk dalam pelatihan khusus yang disebut dengan pusat latihan daerah. Dalam pelatihan tersebut, atlet akan dibimbing dan diawasi langsung oleh pelatih yang telah ditunjuk oleh pihak Komite Olahraga Nasional Indonesia dan Induk Organisasi Cabang Olahraga yang bersangkutan. Pelatih yang ditetapkan tersebut akan dipusatkan dalam 1(satu) tempat pelatihan dalam perkumpulan cabang olahraga yang biasanya terdapat di ibu kota provinsi. Dalam menjalankan tugasnya, atlet prestasi dan pelatih atlet prestasi tersebut diikat oleh kontrak kerja yang masa waktunya 6(enam) bulan hingga 12(dua belas) bulan. Namun, sebelum melakukan kontrak pihak Komite Olahraga Nasional Indonesia dan Induk Organisasi Cabang Olahraga melakukan penelaahan serta evaluasi terhadap prestasi yang telah dibuat oleh atlet maupun pelatih. Apabila telah memasuki kriteria maka, atlet dan pelatih dapat masuk dalam kategori atlet prestasi dan pelatih atlet prestasi.

Dalam penjelasaan sebelumnya, kontrak kerja yang mengikat atlet prestasi dan pelatih atlet prestasi memiliki masa waktu. Selama dalam masa waktu kontrak, atlet prestasi diberikan sebuah beban atau kewajiban yaitu, setiap bulan akan selalu dilakukan evaluasi terhadap prestasi atlet. Sebagai contoh, dalam 6(enam) bulan terdapat sebanyak 2(dua) pertandingan, maka dari hasil 2(dua) pertandingan tadi akan didapatkan hasil kinerja atlet. Dari hasil pertandingan tersebut pihak Komite Olahraga Nasional Indonesia dan Induk Organisasi Cabang Olahraga dapat melakukan penelaahan dan evaluasi kembali, mengenai kinerja atlet prestasi tersebut menjadi turun, stabil, atau meningkat. Apabila dari hasil evaluasi tersebut ditemukan penurunan kinerja atlet maka, pihak Komite Olahraga Nasional Indonesia dengan 
mengutus Induk Organisasi Cabang Olahraga akan memberikan pemberitahuan bahwa apabila dalam 1(satu) kali pertandingan kedepan atlet yang bersangkutan harus menaikkan kembali kinerjanya, dan apabila terbukti menurun kembali maka konsekuensi yang didapat adalah atlet akan dicopot dari kategori atlet prestasi dan otomatis kontrak kerja telah selesai.

Saat ini penulis memiliki contoh kasus yang dapat dijadikan bahan pembahasan yang dapat dijabarkan sebagai berikut. Terdapat seorang atlet prestasi yang berhasil masuk dalam pelatihan daerah dan kemudian atlet prestasi tersebut mendapat kontrak kerja dengan pihak Komite Olahraga Nasional Indonesia dan Induk Organisasi Cabang Olahraga dengan diketahui oleh pengurus Pelatihan Daerah Perkumpulan Cabang Olahraga yang bersangkutan. Kontrak kerja yang dimaksud di atas memiliki masa waktu selama 6(enam) bulan, namun baru 2(dua) bulan berjalan, di bulan ke 3(tiga) atlet prestasi yang bersangkutan tidak dimendapatkan upah yang seharusnya didapatkan seperti bulan sebelumnya yaitu sebesar Rp 3.500.000 (tiga juta lima ratus ribu rupiah). Setelah atlet prestasi tersebut mencari informasi, yang didapatkan adalah ia diberhentikna secara sepihak oleh pihak Induk Organisasi Cabang Olahraga tanpa keterangan yang jelas. Dalam waktu 2 (bulan) saat ia masih dalam masa terikat kontrak, tidak ada pertandingan yang berlangsung dan tidak dimungkinkan pula bila pihak Induk Organisasi Cabang Olahraga melakukan evaluasi atlet hanya dengan berdasar pada latihan sehari-hari yang dilakukan atlet ditempat pelatihan. Sebab hal tersebut tidaklah dapat dijadikan bahan atau dasar evaluasi karna tidak termasuk dalam pertandingan. Sangat disayangkan pula, dalam pemberhentian atlet prestasi tersebut pihak Induk Organisasi Cabang Olahraga tidak memberikan surat peringatan terlebih dahulu apabila memang atlet prestasi yang bersangkutan melakukan tindakan yang menyimpang maupun kinerjanya menurun. Saat terus ditanya mengenai apa yang membuat atlet prestasi tersebut diberhentikan dari pusat pelatihan daerah dan diminta untuk menyertakan surat keterangan pemberhentian agar atlet prestasi yang bersangkutan mengerti letak kesalahannya, pihak Induk Organisasi Cabang Olahraga enggan untuk menyampaikan alasan pemberhentian dan menyerahkan surat resmi pemberhentian atlet prestasi tersebut. 


\section{Pengertian Hukum Perburuhan}

Tiap-tiap manusia tentu dapat dipastikan tidak akan bisa bertahan hidup secara mandiri tanpa adanya bantuan dari orang lain. Dengan begitu, hukum positif di Indonesia membantu mengatur hubungan yang akan terjadi antara manusia satu dengan manusia lainnya yang kemudian akan berdampak dengan kinerja masing-maisng indivudu tersebut. Hukum positif yang mengatur hal ini adalah Hukum Perburuhan. Hukum Perburuhan adalah sebagian dari hukum yang berlaku (segala peraturan-peraturan) yang menjadi dasar dalam mengatur hubungan kerja antara buruh (pekerja) dengan majikan atau perusahaannya, mengenai tata kehidupan dan tata kerja yang langsung bersangkut paut dengan hubungan kerja tersebut. ${ }^{5}$ Namun Mr. Molenaar memilik pendapat tersendiri mengenai pengertian hukum perburuhan yaitu, bahwa Hukum Perburuhan (Arbeidrechts) adalah bagian dari hukum yang berlaku yang pada pokoknya mengatur hubungan antara buruh dan majikan, buruh dengan buruh, dan buruh dengan penguasa. ${ }^{6}$ Hampir sama dengan Mr. Molenaar, Prof Imam Soepomo memiliki pengertian bahwa Hukum perburuhan adalah suatu himpunan peraturan, baik tertulisa maupun tidak yang berkenaan dengan kejadian di mana seseorang bekerja pada orang lain dengan menerima upah. ${ }^{7}$

Dari beberapa perumusan pengertian mengenai Hukum Perburuhan yang telah dijabarkan oleh beberapa ahli diatas, dapat dijabarkan bahwa unsur-unsur dari Hukum Perburuhan adalah sebagai berikut: ${ }^{8}$

a. Adanya serangkaian peraturan baik tertulis maupun tidak tertulis;

b. Peraturan tersebut mengenai suatu kejadian;

c. Adanya orang (buruh/pekerja) yang bekerja pada pihak lain (majikan);

d. Adanya upah yang diberikan.

Dari penjabaran unsur-unsur diatas, maka dapat ditarik kesimpulan bahwa makna dari Perburuhan adalah suatu pekerjaan dimana seseorang yang disebut buruh akan bekerja pada seorang majikan yang kemudian menerima sejumlah uang atau yang biasa disebut dengan upah.

\footnotetext{
${ }^{5}$ RG. Karta Sapoetro dan RG. Widianingsih, Pokok-pokok Hukum Perburuhan (Cetakan ke-1, 1982).[2].

${ }^{6}$ ibid.

${ }^{7}$ Imam Soepomo, Pengantar Hukum Perburuhan (Cetakan ke-IV, Djambatan 1983).[3].

${ }^{8}$ Zainal Asikin, Dasar-Dasar Hukum Perburuhan (Rajawali Pers 2010).[3].
} 


\section{Pihak-Pihak dalam Hukum Perburuhan}

Dalam sebuah pengaturan hukum, tentu tidak terlepas dari adanya pihak bersangkutan yang akan diatur dalam peraturan tersebut. Dalam hukum perburuhan yang menjadi pihak-pihak dalam hal ini adalah sebagai berikut: ${ }^{9}$

a. Buruh dan Majikan;

b. Organisasi Buruh;

c. Organisasi Majikan;

d. Pemerintah (penguasa);

e. Pengawasan.

\section{Perjanjian Kerja}

Pengertian perjanjian kerja menurut peraturan perundang-undangan yang berlaku di Indonesia, yang pertama adalah menurut Pasal 1601a BW, Perjanjian Kerja adalah suatu perjanjian dimana pihak yang satu si buruh, mengikatkan dirinya untuk di bawah perintahnya pihak lain, si majikan untuk suatu waktu tertentu, melakukan pekerjaan dengan menerima upah. Yang kedua adalah berdasarkan pada Pasal 1 angka 14 Undang-Undang Nomor 13 Tahun 2003 tentang Ketenagakerjaan, Perjanjian Kerja adalah perjanjian antara pekerja/buruh dengan pengusaha atau pemberi kerja yang memuat syarat-syarat kerja, hak, dan kewajiban para pihak. Perjanjian Kerja sendiri dibagi menjadi 2(dua), yaitu:

1. Perjanjian Kerja untuk Waktu Tertentu atau yang disingkat dengan PKWT. Perjanjian tersebut dibuat berdasarkan jangka waktu yang telah ditentukan atau berdasarkan selesainya pekerjaan tersebut atau mengenai pekerjaan tertentu. Perjanjian kerja untuk Wakttu Tertentu ini harus dibuat secara tertulis dengan menggunakan bahasa Indonesia dan tulisan latin serta memuat sekurangkurangnya: ${ }^{10}$

a. Nama, alamat perusahaan, dan jenis usaha;

b. Nama, jenis kelamin, umur dan alamat pekerja;

c. Jabatan atau jenis pekerjaan;

d. Tempat pekerjaan;

${ }^{9}$ ibid.[39].

${ }^{10}$ F.X. Djumialdji, Perjanjian Kerja (Sinar Grafika, 2005).[21-22]. 
e. Besarnya upah dan cara pembayarannya;

f. Syarat-syarat kerja yang memuat hak dan kewajiban pengusaha dan pekerja;

g. Mulai dan jangka waktu berlakunya perjanjian kerja;

h. Tempat dan tanggal perjanjian kerja dibuat;

i. Tanda tangan para pihak dalam perjanjian kerja.

Dalam Perjanjian Kerja untuk Waktu Tertentu ini juga dapat dibedakan lagi menjadi 2 (dua), yaitu berdasarkan waktu tertentu dan berdasarkan pekerjaan tertentu. Apabila berdasarkan waktu tertentu maka, perjanjian tersebut didasarkan atas jangka watu tertentu yang diadakan paling lama 2 (dua) tahun dan hanya dapat diperpanjang sebanyak 1 (satu) kali dengan jangka waktu paling lama 1 (satu) tahun. Sedangkan apabila berdasarkan pekerjaan tertentu maka, perjanjian tersebut akan dilihat lagi mengenai penyelesaian kerjanya yang sifatnya paling lama 3 (tiga) tahun, sifatnya musiman, atau sifatnya berhubungan dengan produk baru. Karena ketiga sifat dari Perjanjian Kerja untuk Waktu Tertentu yang berdasarkan pekerjaan tertentu tersebut memiliki kriteria masing-masing sesuai dengan sifatnya. Namun dari kedua jenis Perjanjian Kerja untuk Waktu Tertentu tersebut memiliki persamaan yaitu untuk melakukan perpanjangan perjanjian kerja, pengusaha dapat melakukannya paling lama 7 (tujuh) hari sebelum perjanjian kerja yang berlaku belum berakhir. Tetapi apabila perjanjian kerja tersebut telah berakhir dan belum dilakukannya perpanjangan waktu maka dapat diadakan pembaruan dengan ketentuan jika jangka waktu paling sedikit setelah 30 (tiga puluh) hari setelah masa tenggang dan paling lama 2 (dua) tahun.

2. Perjanjian Kerja untuk Waktu Tidak Tertentu atau yang disingkat dengan PKWTT. Perjanjian tersebut dibuat berdasarkan pada pekerjaan yang bersifat tetap. Perjanjian kerja untuk Wakttu Tidak Tertentu ini dapat dibuat secara tertulis maupun lisan. Apabila dibuat secara lisa maka, pengusaha wajib membuat surat pengangkatan yang sekurang-kurangnya memuat keterangan:
a. Nama dan alamat pekerja;
b. Tanggal mulai bekerja;
c. Jenis pekerjaan;
d. Besarnya upah. 
Dari kedua jenis perjanjian kerja yang telah diterangkan diatas, memiliki isi perjanjian yang telah diatur sesuai dengan peraturan perundang-undangan yaitu tidak boleh isi dari perjanjian kerja bertentangan dengan perturan perusahaan, perjanjian kerja bersama, dan peraturan perundang-undangan yang berlaku. Apabila didalam perusahaan telah ada peraturan perusahaan atau perjanjian kerja bersama, isi perjanjian kerja tidak boleh lebih rendah dari peraturan perusahaan ataupun perjanjian kerja bersama yang berlaku di perusahaan yang bersangkutan. ${ }^{11}$

\section{Pengertian Hubungan Industrial}

Hubungan Industrial di beberapa buku menyebut dengan Hubungan Industrial Pancasila (HIP) yang memiliki pengertian, yaitu suatu sistem hubungan yang terbentuk anatara para pelaku dalam proses produksi barang dan jasa (pekerja, pengusaha, dan pemerintah) yang didasarkan atas nilai-nilai yang merupakan manifestasi dari keseluruhan sila-sila dari Pancasila dan Undang-Undang Dasar 1945 yang tumbuh dan berkembang di atas kepribadian bangsa dan kebudayaan nasional Indonesia. ${ }^{12}$ Namun menurut Adrian Sutedi, Hubungan Industrial pada dasarnya adalah proses terbinanya komunikasi, konsultasi musyawarah serta berunding dan ditopang oleh kemampuan dan komitmen yang tinggi dari semua elemen yang ada di dalam perusahaan. ${ }^{13}$

\section{Prinsip-Prinsip Dasar Hubungan Industrial}

Hubungan Industrial Pancasila memiliki ciri-ciri khusus yang sebagai berikut: ${ }^{14}$

a. Mengakui dan meyakini bahwa bekerja bukan hanya bertujuan untuk sekedar mencari nafkah saja tetapi sebagai pengabdian manusia kepada Tuhan, kepada sesame manusia, kepada masyarakat, bangsa, dan Negara.

b. Menggap pekerja/buruh bukan hanya sekedar factor produksi belaka, tetapi sebagai manusia pribadi dengan segala harkat dan martabat.

c. Melihat antara pekerja/buruh dan pengusaha bukanlah mempunyai jeoentingan

\footnotetext{
${ }^{11}$ ibid.[22].

${ }^{12}$ Sedjun. H. Manulang, Pokok-pokok Hukum Ketenagakerjaan (Rineka Cipta, 1990).[145].

${ }^{13}$ Adrian Sutedi, Hukum Perburuhan (Sinar Grafika, 2009).[23].

${ }^{14}$ ibid.[27].
} 
yang bertentangan, tetapi mempunyai kepentingan yang sama, yaitu kemajuan perusahaan.

d. Memandang setiap perbedaan pendapat antara pekerja/buruh dan pengusaha harus diselesaikan dengan jalan dilakukan secara kekeluargaan.

e. Menjaga keseimbangan antara hak dan kewajiban kedua belah pihak, yang dicapai bukan didasarkan atas perimbangan kekuatan (balance of power), tetapi atas dasar rasa keadilan dan kepatuhan.

\section{Hubungan Kerja}

Pengertian Hubungan kerja menurut Kitab Undang-Undang Hukum Perdata (BW) Pasal 1601a adalah suatu perjanjian dimana pihak yang satu (buruh), mengikatkan diri untuk bekerja pada pihak yang lain (majikan) selama waktu tertentu dengan menerima upah. Berbeda dengan BW, Prof Soepomo mengemukakan bahwa perjanjian kerja adalah suatu perjanjian dimana pihak yang satu (buruh) mengikatkan diri untuk bekerja pada pihak lain (majikan) selama waktu tertentu dengan menerima upah dari pihak lain (majikan) dan pihak majikan wajib pula mengikatkan diri untuk mempekerjakan buruh dengan kewajiban membayar upah. ${ }^{15}$ Selanjutnya, berdasarkan pengertian tentang hubungan kerja pada Pasal 1 angka 15 Undung-Undang Nomor 13 Tahun 2003 tentang Ketenagakerjaan didapatkan bahwa unsur dari sebuah hubungan kerja adalah adanya pekerjaan, adanya perintah dan adanya upah.

\section{Pengertian Perselisihan Hubungan Industrial}

Menurut Undang-Undang Nomor 2 Tahun 2004 Pengertian dari perselisihan hubungan industrial adalah perbedaan pendapat yang mengakibatkan pertentangan antara pengusaha dengan pekerja/buruh atau serikat pekerja/serikat buruh karena terdapat perselisihan mengenai hak, perselisihan pemutusan hubungan kerja, serta perselisihan antar serikat pekerja/serikat buruh dalam satu perusahaan. Berdasarkan pengertian tersebut dapat dilihat bahwa yang dapat bertindak sebagai pihak dari pekerja/buruh dalam perselisihan hubungan industrial tidak hanya organisasi serikat pekerja/serikat buruh melainkan perseorangan dari pekerja/buruh atau sekelompok

\footnotetext{
15 ibid. [46].
} 
pekerja/buruh juga dapat menjadi pihak dalam perselisihan hubungan industrial. Menurut Adrian Sutedi dalam bukunya Perselisihan Hubungan Industrial memiliki pendapat bahwa perselisihan hubungan industrial meliputi sebagai berikut: ${ }^{16}$

a. Perselisihan hak, yang disebabkan karena tidak dipenuhinya hak akibat adanya perbedaan pelaksanaan atau penafsiran terhadap ketentuan dasar peraturan dalam perusahaan tersebut

b. Perselisihan kepentingan, yang disebabkan karena tidak adanya persesuaian pendapat mengenai pembuatan dan/atau perubahan syarat-syarat kerja dalam ketentuan dasar peraturan dan perjanjian antara majikan dan pekerja/buruh.

c. Perselisihan pemutusan hubungan kerja, yang disebabkan karena tidak adanya kesesuaian pendapat mengenai masa berakhir tugas kerja yang dilakukan oleh salah satu pihak.

d. Perselisihan antar serikat pekerja/serikat buruh dalam satu perusahaan, yang disebabkan karena tidak adanya persesuaian paham mengenai keanggotaan, pelaksanaa hak dan kewajiban keserikatpekerjaan.

\section{Macam-Macam Penyelesaian Perselisihan Hubungan Industrial}

Menurut Adrian Sutedi dalam bukunya Hukum Perburuhan bahwa setiap perselisihan hubungan industrial wajib diupayakan suatu penyelesaian terlebih dahulu yang kemudian penyelesaian perselisihan perburuhan tersebut dibagi menjadi 2 (dua) cara yaitu penyelesaian perselisihan melalui di luar jalur pengadilan hubungan industrial dan penyelesaian perselisihan melalui jalur pengadilan hubungan industrial.

Dalam penyelesaian perselisihan perburuhan melalui jalur di luar pengadilan, dibagi lagi menjadi 4 (empat) upaya perundingan yang dapat dilakukan apabila tidak dicapai suatu kesepakatan antara para pihak yang berselisih dalam musyawarah, yaitu: ${ }^{17}$

1. Bipartit;

2. Mediasi;

3. Konsiliasi;

4. Arbitrase.

\footnotetext{
${ }^{16}$ ibid.[105].

${ }^{17}$ Adrian Sutedi, Hukum Perburuhan, Loc. Cit.[104].
} 


\section{Proses Penyelesaian Kasus antara Pihak Organisasi Komite Nasional Indonesia dengan Atlet Pada Pusat Latihan Daerah}

Sesuai yang telah dijelaskan sebelumnya Penyelesaian Perselisihan Perburuhan dapat dilakukan melalui 2 (dua) macam cara yaitu melalui jalur Pengadilan Hubungan Industrial atau yang biasa disebut dengan Litigasi dan melalui jalur di luar Pengadilan Hubungan Industrial atau yang biasa disebut dengan Non-Litigasi. Dalam kasus posisi yan telah dijabarkan diatas, perselisihan antara Atlet pada Pusat Latihan Daerah dengan Pihak Organisasi Komite Nasional Indonesia ada 2 yaitu mengenai perselisihan hak dan perselisihan pemutusan hubungan kerja. Pada kedua permasalahan perselisihan diatas dapat dilakukan 3 upaya hukum melalu penyelesaian perselisihan perburuhan di luar pengadilan hubungan industrial (Non-Litigasi) yaitu, Bipartit, Namun apabila Bipartit tidak mencapai kesepakatan maka kedua belah pihak dapat mengajukan upaya hukum Mediasi untuk perselisihan hak, dan Konsiliasi untuk perselisihan pemutusan hubungan kerja.

Sedangkan apabila dalam upaya penyelesaian melalui jalur di luar Pengadilan Hubungan Industrial (Non-Litigasi) tidak dapat mencapai kesepakatan, maka kedua belah dapat mengajukan upaya hukum yang melibatkan Pengadilan Hubungan Industrial pada Pengadilan Negeri di wilayah setempat (Litigasi). Karena permasalahan perselisihan perburuhan dalam hal ini adalah perselisihan hak dan perselisihan pemutusan hubungan kerja, apabila salah satu pihak nantinya menolak hasil putusan dari Pengadilan Hubungan Industrial maka, pihak yang menolak tersebut dapat melakukan upaya hukum tingkat terakhir yaitu melakukan permohonan kasasi atau peninjauan kembali ke Mahkamah Agung yang diajukan secara tertulis melalui Panitera Pengadilan Negeri setempat dengan tenggang waktu paling lama 30 (tiga puluh) hari kerja terhitung sejak tanggal penerimaan permohonan kasasi atau peninjauan kembali disampaikan kepada pihak yang bersangkutan. 


\section{Kesimpulan}

Berdasarkan penjelasan diatas, terdapat hubungan antara Atlet pada Pusat Latihan Daerah dengan Organsisasi Komite Olahraga Nasional Indonesia yang diatur dalam hukum perburuhan. Kedua pihak dalam kasus ini adalah termasuk dalam hubungan industrial antara majikan dan pekerja/buruh yang dibuktikan dengan adanya perjanjian yang berbentuk Surat Keputusan yang dibuat oleh Pihak Organsisasi Komite Olahraga Nasional Indonesia dengan Atlet selaku majikan yang berisikan tentang hak dan kewajiban bagi Atlet pada Pusat Latihan Daerah yang namanya tercantum dalam Surat Keputusan tersebut. Namun sebagaimana isi dalam Surat Keputusan tersebut, tidak memberikan klasula tentang pemutusan kontrak secara pihak. Akibat perselisihan antara Pihak Organsisasi Komite Olahraga Nasional Indonesia dengan Atlet pada Pusat Latihan Daerah mengenai perselisihan hak dan perselisihan pemutusan hubungan kerja yang masing-masing dari kedua perselisihan tersebut dapat diselesaikan melalui upaya hukum di luar Pengadilan Hubungan Industrial yaitu melalui mediasi dan konsiliasi. Apabila melalui upaya hukum di luar Pengadilan Hubungan Industrial tidak dapat mencapai kesepakatan, maka kedua belah pihak dapat mengajukan permohonan penyelesaian perselisihan melalui upaya hukum di Pengadilan Hubungan Industrial.

\section{Daftar Bacaan}

\section{Buku}

Asikin Zainal, Dasar-Dasar Hukum Perburuhan (Cetakan ke-VIII, 2010).

Djumialdji F.X., Perjanjian Kerja (Sinar Grafika 2005).

Kartasapoetro RG. dan RG. Widianingsih, Pokok-pokok Hukum Perburuhan (Armico, Cetakan ke-1, 1982).

Manulang Sedjun. H., Pokok-pokok Hukum Ketenagakerjaan (Rineka Cipta 1990). Soepomo Imam, Pengantar Hukum Perburuhan (Cetakan ke-IV, 1983)

Sutedi Adrian, Hukum Perburuhan (Sinar Grafika 2009) 


\section{Laman}

KBBI, Atlet, Kamus Besar Bahasa Indonesia (KBBI 2018), <https://kbbi.web.id/ atlet,> accessed 18 Februari 2019.

KBBI, Olahraga, Kamus Besar Bahasa Indonesia (KBBI 2018), <https://kbbi.web. id/olahraga,> accessed 18 Februari 2019.

Vannisa, Pengertian olahraga secara umum \& menurut para ahli adalah, Perpustakaan Online Nasional (Perpustakaan Nasional 2017)< https:// perpustakaan.id/pengertian-olahraga-secara-umum-menurut-para-ahliadalah/,> accessed 18 Februari 2019.

\section{Perundang-undangan}

Undang-Undang Nomor 03 Tahun 2005 tentang Sistem Keolahragaan Nasional (Lembaran Negara Republik Indonesia Tahun 2005 Nomor 89).

HOW TO CITE: Dio Novandra Wibawa, 'Perlindungan Hukum Terhadap Atlet Pelatihan Daerah Dengan Organisasi Komite Olahraga Nasional Indonesia Terkait Kontrak Kerja' (2019) Vol. 2 No. 6 Jurist-Diction. 
--halaman ini sengaja dibiarkan kosong-- 